\title{
When formulation procedures strongly matter: a case study of ayahuasca use in Centro Luz Divina, Piedade, São Paulo, Brazil
}

\author{
Arilton Martins Fonseca ${ }^{1 *}$ (D), Eliana Rodrigues ${ }^{1}$ (D) \\ ${ }^{1}$ Universidade Federal de São Paulo (UNIFESP), Programa de Pós-graduação em Biologia Química, São Paulo, SP, Brasil \\ *Corresponding author: ariltonmf@gmail.com
}

\begin{abstract}
Objectives: The objectives of this study were (a) to describe the history of the formation of the Centro Luz Divina (CLD), Piedade, São Paulo, (b) to describe the plants and recipes involved in making ayahuasca, and (c) to provide information for future chemical and pharmacological studies of ayahuasca. Methods: During the 578 hours of fieldwork between 2017 and 2019, 10 interviewees were interviewed (two priests and eight CLD leaders). The methods and techniques from cultural anthropology were used to conduct a snowball sampling to select respondents and record data through unstructured interviews, participant observation and field diaries. Data on the history of the CLD's formation, plants and beverage recipes were recorded. The plants were dry collected and deposited at the UNIFESP Herbarium. Results: The history of the formation of the CLD, which was founded in 2002, was detailed. This center produces several recipes of the ayahuasca beverage during rituals named feitios in Portuguese by using the plants Psychotria viridis and Banisteriopsis caapi. The process of making two of these recipes was detailed in the present study, and they are the "First Degree beverage" and "Second Degree beverage", which vary in preparation time, concentration, diversity and amount of the plant used and may lead to different "potencies of the beverage", according to the interviewees' reports. From a pharmacological point of view, higher degree beverages are probably richer beverages from the chemical and pharmacological perspectives. Conclusion: Ayahuasca recipes produced at the CLD may have different "potencies". However, future chemical and pharmacological investigations should consider these and other types of ayahuasca found in other Daimist centers in their protocols since many studies suggest the use of the substances in this beverage for treating Parkinson's, anxiety, depression, and other ailments, as described in the scientific literature.
\end{abstract}

Keywords: Alkaloids. Ayahuasca. Ethnography. Ethnopharmacology. Medicinal plants.

\section{How to cite}

Fonseca AM, Rodrigues E. When formulation procedures strongly matter: a case study of ayahuasca use in Centro Luz Divina, Piedade, São Paulo, Brazil. Rev Ciênc Farm Básica Apl. 2021;42:e720. https://doi.org/10.4322/2179-443X.0720

\section{INTRODUCTION}

Ayahuasca is a beverage originally used by indigenous and mestizo populations in South America, specifically, in the Upper Amazon Basin region in Brazil and in other countries such as Colombia, Peru, Venezuela, Bolivia and Ecuador". Ayahuasca, a Quechua word, means "vine 
of the dead" or "wine of souls". ${ }^{2}$ The beverage is prepared from a decoction of two plants: from the bark stems and vines of Banisteriopsis caapi (Spruce ex Griseb.) Morton (Malpighiaceae), which is popularly called mariri, caapi, and jagube, from which $\beta$-carbolines Harmina (HRM), Harmalina (HRL) and Tetrahydroharmina (THH) are extracted; and the leaves of Psychotria viridis Ruiz \& Pav. (Rubiaceae), which is called chacrona or queen, whose leaves contain the psychodysleptic alkaloid N,N-dimethyltryptamine (DMT) $)^{3,4}$. This decoction varies in preparation time, the diversity of the plants used, and the proportion of the plants used in each recipe. Therefore, there are various types of ayahuasca beverages ${ }^{5-7}$.

In Brazil, the ayahuasca beverage is used in religions called "ayahuasqueiras", ${ }^{6}$ and the main three religions are Santo Daime, Barquinha and União do Vegetal. The first was founded by an ex-rubber tapper, Raimundo Irineu Serra (Mestre Irineu) in the early 1930s in the city of Rio Branco, Acre ${ }^{8}$. Barquinha appeared in 1945, also in Rio Branco, and was created by Frei Daniel Pereira de Mattos. In the 1960s, Mestre José Gabriel da Costa established the Centro Espírita Beneficente União do Vegetal (UDV) in Porto Velho, Rondônia ${ }^{8}$. At the end of the 1970 s and 1980s, UDV and Santo Daime grew in popularity in the large urban centers of the country and abroad (the USA, Spain, Italy, France, the Netherlands, and Japan, among others); Barquinha was the only religion to remain restricted to its nation of origin ${ }^{\text {. }}$

The ceremonies in the Daimist doctrine revolve around the collective ingestion of the ayahuasca beverage (Daime) to the sound of "hymns" through which its teachings are transmitted, which makes it "a musical doctrine". ${ }^{10}$

The ayahuasca beverage is not considered a drug or a hallucinogen; specifically, in Santo Daime, it is considered to be a sacrament akin to "the blood of Christ" or a "divine being" who has great powers, including what they call its "own will" (vontade própria). Thus, when a person ingests the beverage, he "comes into direct contact with the divine" by referring to its entheogenic effect ${ }^{10}$ related to the idea of "having the divine within". ${ }^{11}$ The idea that certain plants provide access to knowledge links them to the concept of "master plants" or "teaching plants", which is the case for ayahuasca. ${ }^{12}$ "Master plants" are often considered to be inhabited by a spirit or "mother"; they are intelligent beings, with their own personality and with whom someone can acquire knowledge and form a relationship ${ }^{13,14}$.

Some centers and churches currently produce their own ayahuasca beverage from the cultivation of the two species of plants that compose it due to the high demand for the consumption of this beverage. An overview of ayahuasca consumption was presented in 2015 by the Oswaldo Cruz Foundation (FIOCRUZ) when carrying out the third National Survey on the Use of Drugs by the Brazilian Population (III LNUD). In this study, 16,273 people aged between 12 and 65 years old were interviewed. The results suggested that 567 people had used ayahuasca at least once in their lives. Of these, 181 people used it in the last year, and 118 consumed ayahuasca in the 30 days prior to the survey. The study presented an unprecedentedly high estimate of use of the ayahuasca beverage among the Brazilian population ${ }^{15}$.

The potential use of ayahuasca as an herbal medicine is directly linked to the action of the active compounds (DMT, HRM, HRL and THH) in the beverage ${ }^{16}$. Ayahuasca has potential applications in addiction treatment, namely, in treatments for the misuse of alcohol, tobacco and illicit drugs such as cocaine and heroin ${ }^{17-22}$, as well as for depression ${ }^{23-25}$, and anxiety ${ }^{26,27}$.

Studies on psychodysleptics have shown that they increase neuritogenesis and/or spinogenesis in vitro - that is, the ability to increase the proliferation of dentate gyrus cells in the hippocampal formation in nonhuman mammals - in living beings from the main alkaloids present in ayahuasca (DMT, HRM, HRL and THH) ${ }^{28,29}$ and in human cells ${ }^{30}$. Nevertheless, preclinical studies suggest that HRM may have neuroprotective and cognitive enhancement effects; therefore, the prolonged use of ayahuasca, which is rich in HRM, may be associated with better neuropsychological performance ${ }^{31}$. In this sense, studies on the therapeutic potential of ayahuasca as a medicine based on its active compounds (DMT, HRM, HRL and $\mathrm{THH}$ ) are of prime importance.

The present study is the result of the researchers' shared interests in studying the ritual consumption of the ayahuasca beverage based on the ritual practices of the Centro Luz Divina 
(CLD), Céu de Midam Community, Piedade, São Paulo. Thus, the objectives of this study were (a) to describe the history of the formation of the CLD, (b) to describe the plants and recipes involved in making CLD ayahuasca, and (c) to provide elements for future chemical and pharmacological studies with ayahuasca.

\section{MATERIAL AND METHODS}

The diagram below (Figure 1) summarizes the interfaces of this study, showing all the stages of its realization.

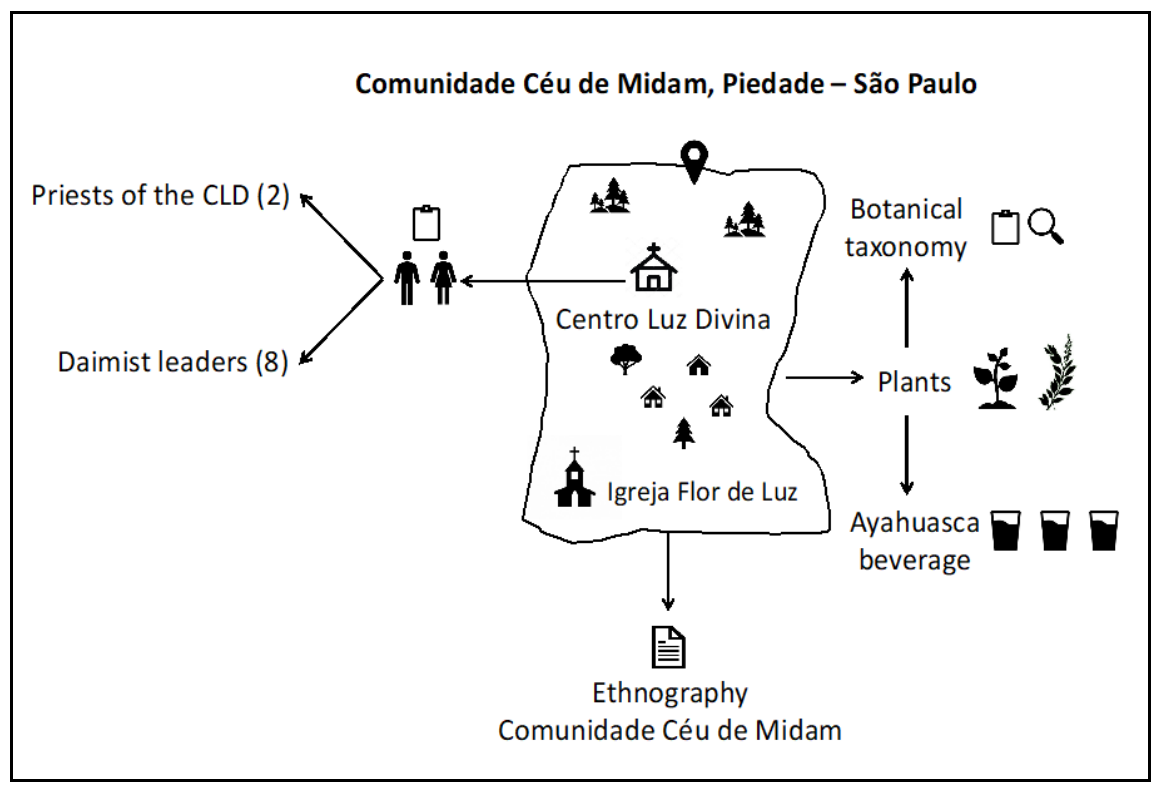

Figure 1 - Scheme on the interfaces of the present study and the stages of its realization. Source: Author AMF (2021).

For this study, legal permits were obtained 1. to access traditional knowledge: National System for the Management of Genetic Heritage and Associated Traditional Knowledge (SisGen), registration number A4A9C67; 2. to collect and transport plants: Biodiversity Authorization and Information System (SISBIO), process no. 73895; and 3. to carry out this research at the Universidade Federal de São Paulo (UNIFESP): Research Ethics Committee of UNIFESP/EPM (CEP/EPM), file no. 2.877.224.

Starting in mid-February 2017, several conversations and meetings were held between the researchers and the CLD leaders (totaling 24 hours). The researchers participated in three rituals at the CLD between November 2018 and October 2019 (72 hours), visits were made to the CLD and the Comunidade Céu de Midam (32 hours), and recorded interviews were conducted with CLD and other leaders (36 hours) between July 10 and 15, 2018, and January 14 and 25, 2019, which totaled 578 hours of fieldwork.

To collect data on the history of the CLD's formation, the recipes involved in making the ayahuasca beverage and the plants that compose it, field methods used in cultural anthropology were used, including unstructured interviews, participant observations and field diaries $^{32,33}$. Snowball sampling was used; thus, the priests of the CLD (a godmother and godfather) listed the names of some Daimist leaders who had been participating since the formation of the Igreja Flor de Luz (Comunidade Céu de Midam), and these leaders connected the researchers with other leaders, which exhausted the intended sample ${ }^{32}$. Bernard ${ }^{32}$ notes that this type of sampling is appropriate for small populations where people are in contact with one another; therefore, it is an effective means of building an exhaustive sample. Thus, 
the interviews were conducted with 10 people, namely, two priests from the CLD and eight other leaders.

The interview sheet on the formation of the CLD addressed the following open questions: How did the CLD form? Who participated in this process? When was the CLD founded? The recipe sheet covered questions on the plants involved, the quantity of each plant used, the method of preparation, and the special care taken in collecting and storing the plants before preparing the beverage.

In July 2018, samples of the plants (with flowers and/or fruits) were photographed and collected at the CLD site during the interviews conducted with the priests. The botanical data sheet (including the plant name and code, date and place of collection, type of environment, presence of an aroma, flavor or exudate, and months of flowering and fruiting) was also completed during the collection of the plants. The material was collected, pressed and dried by using the dry method of collection in accordance with Alexiades ${ }^{34}$; then, the material was identified by taxonomists at the Botanical Institute of São Paulo State (IBt-SP), and a voucher sample was deposited at the institute.

\section{RESULTS AND DISCUSSION}

To understand the formation and constitution of the CLD, it is first necessary to understand the historical facts regarding the formation of the Igreja Flor de Luz by the godfather, Jonas Frederico.

Throughout the data collection, CLD priests and leaders who witnessed the process and two sons of Jonas Frederico were interviewed. Jonas was born in Amparo, São Paulo State, on July 14, 1935, but he moved to Goiás State where he married and had four children. In 1971, he was introduced to Padrinho Sebastião Mota de Melo in the city of Rio Branco, Acre State. This meeting allowed him to bring the ayahuasca beverage to the midwestern and southeastern regions of Brazil through Padrinho Sebastião. For this reason, he is considered to be a pioneer of Santo Daime in these regions; he started organizing meetings at which Daime (ayahuasca beverage) was first drunk in Goiás and later in São Paulo. In January 1980, he moved from Goiás to São Paulo State in search of treatment because of serious kidney problems. In 1992, he had a stroke, with no sequelae, and also began experiencing heart problems around 1995 or 1996 when he underwent bypass surgery.

Jonas's family reported that he had a "miraçãoa" during one of the rituals: he saw a hummingbird sucking some of his veins. The fact is that Jonas had health problems for many years and was given a poor prognosis by the doctors at Hospital das Clínicas, Faculdade de Medicina da Universidade de São Paulo. The Daimist community believed that Daime (ayahuasca beverage) helped him recover from his health problems.

Forming an association between religion and health is a way of addressing difficulties or suffering and is known as "religious coping".35,36 Generally, coping, or religious coping, is used in situations of crisis or psychological stress. According to Machado and Holanda ${ }^{37}$, religious coping can be explained as the use of beliefs to facilitate a resolution or to prevent or alleviate the consequences of suffering, which defines the way in which an individual faces her difficulties.

Sanchez and $\mathrm{Nappo}^{38}$ affirm that compared to people who are treated exclusively by biomedicine, people who attend religious services or practice some type of professed religion (of any denomination) show significant health improvements. Studies have also confirmed the relationship between spirituality and health in the context of quality of life ${ }^{36,39,40}$.

The Daime ritual started around 1983 at Jonas's house in São Paulo; only a few people participated, including friends and family, approximately eight at each session. There was a period when the meetings occurred at other places/houses, which Jonas Frederico called "itinerant Daime". On these occasions, he carried a bag that contained Daime (ayahuasca

a The term "miração" is used in the Santo Daime tradition to designate the visionary state that the drink produces. Groisman ${ }^{46}$ states that the miração is the state of consciousness in which it is possible to have contact with spirituality or perceive it after consuming Daime. 
beverage) and other elements more fundamental to the ritual (candles, incense, glasses, crystals, among others) to the place where the ritual would happen. The meetings took place approximately every 30 to 40 days. During these rituals, the beverage (Daime) was consumed, and the effects lasted approximately three to four hours.

In June 1991, the first public place (a church) was rented to carry out the ayahuasca rituals in the Bairro Chácara Santo Antônio, São Paulo. This was the group's first social contract that constituted a fixed point for the Igreja Flor de Luz, and the contract lasted for approximately two years. In mid-June 1992, the group was composed of approximately 40 members. On December 2, 1992, Jonas Frederico and a group of people founded the Centro Eclético da Fluente Luz Universal Flor de Luz, the future Mother Church of the Comunidade Céu de Midam, in Piedade, São Paulo State.

Some of these adepts already had children, who were introduced to the Santo Daime Doctrine, which has rituals directed at children that last two hours during which a small amount of Daime (ayahuasca beverage) is offered to them by the priests. Many children were "generated in Daime", as some adepts explained during the interviews, because women did not stop using ayahuasca during pregnancy. Babies, shortly after birth, received "Daime" in droppers. Currently, there is a third generation of these children because the children of the children of these families are currently parents and continue to maintain the tradition of offering Daime to their children.

From a legal point of view, there is no obstacle to minors participating in ayahuasca rituals. According to Labate ${ }^{41}$, at Santo Daime, there is no official rule regarding the frequency of minors participating in spiritual work, which is decided according to the nature of the ritual, the relationship that parents have with the Doctrine and a kind of group knowledge that is accumulated and transmitted orally. Nevertheless, according to the author, minors receive a smaller amount of the drink than adults. This issue is a matter of much controversy; however, the Brazilian civil code provides for fatherland power - a civil institution that traditionally acts as the decision-making body regarding all acts related to raising and educating children which includes the right of parents to educate their children how they wish, including educating children from a religious point of view ${ }^{42}$. That is, just as freedom of religion is an individual's constitutional right, so is the freedom of education and the right to raise one's own children.

Between June 1993 and early 1994, the Igreja Flor de Luz changed its address several times. During this period of change, its members/adepts sought to acquire their own space. The brotherhood organized a commission responsible for the search and purchase of land in several places in the states of São Paulo and Minas Gerais, mainly in the interior, far from the bustle of the concrete metropolis.

In December 1993, 18.15 hectares of land were purchased in the municipality of Piedade, São Paulo, which demarcated the future space of the Igreja Flor de Luz and Comunidade Céu de Midam churches. The property in Piedade had been a processing site for onions and lemons; there was a shed and three houses built on it, and it was located at km 110.5 of Highway SP-79 (Raimundo Antunes Soares, in the stretch between Piedade and Votorantim). On March 19, 1994, the first ritual with the Daimist brotherhood took place at the Igreja Flor de Luz.

During the completion of the Comunidade Céu de Midam project, the Igreja Matriz Flor de Luz worked out of the old onion shed on the property. One of the houses was dedicated to women and children, and the other was dedicated to men. The third house served as the cafeteria. Everyone stayed together on weekends and lived in the community.

Guareschi ${ }^{43}$ affirms that the relations that constitute a true community must be egalitarian and occur between people who have equal rights and duties. Nevertheless, according to Guareschi ${ }^{43}$, these relationships imply that everyone has a voice, that everyone is recognized in their uniqueness, that differences are respected, and that community relations also imply the existence of an affective dimension among community members.

One couple, an architect and an engineer, carried out the Comunidade Céu de Midam project (including making a map of the living areas, conservation areas, lakes, roads, streets, 
measurements, and necessary resources and completing documentation with the city hall of Piedade, São Paulo, among other activities). A surveyor was hired to carry out the project by initiating the division of the property into lots, which resulted in the Comunidade Céu de Midam.

Jonas Frederico passed away on December 3, 2001. On November 15, 2002, the CLD was founded. Currently, the CLD, which is affiliated with the Igreja do Culto Eclético da Fluente Luz Universal (ICEFLU ${ }^{b}$ ) - Patrono Sebastião Mota de Melo, operates on land acquired alongside the Comunidade Céu de Midam; this is one of the largest Daimist communities in Brazil and contains 32 houses in which 19 families are de facto residents.

In 1995, the leader of the CLD and the son of Jonas Frederico went to the city of Rondonópolis, Mato Grosso (MT), which is $1,313 \mathrm{~km}$ from Piedade, São Paulo, to collect 200 queen seedlings ( $P$. viridis) and 100 jagube seedlings (B. caapi) to be cultivated in the Comunidade Céu de Midam. These seedlings were originally from Vila Céu do Mapiá, the Santo Daime headquarters, in the state of Amazonas (AM). The person responsible for bringing the first seedlings from Mapiá to Rondonópolis was Mr. Rodolfo, who was a friend of Mestre Irineu and Padrinho Sebastião. Thus, the Comunidade Céu de Midam, Piedade, São Paulo started to be more self-sufficient by cultivating queen and jagube plants on its lands.

Figure 2 shows the location of Vila Céu do Mapiá, AM (the origin of the plants), Rondonópolis City, MT, where Mr. Rodolfo cultivated the seedlings (the distance between Mapiá and Rondonópolis is 1,685 km), and the locality of the Comunidade Céu de Midam, Piedade, São Paulo, where the seedlings brought from Rondonópolis were cultivated (the distance between Rondonópolis and Comunidade Céu de Midam is 1,313 km).

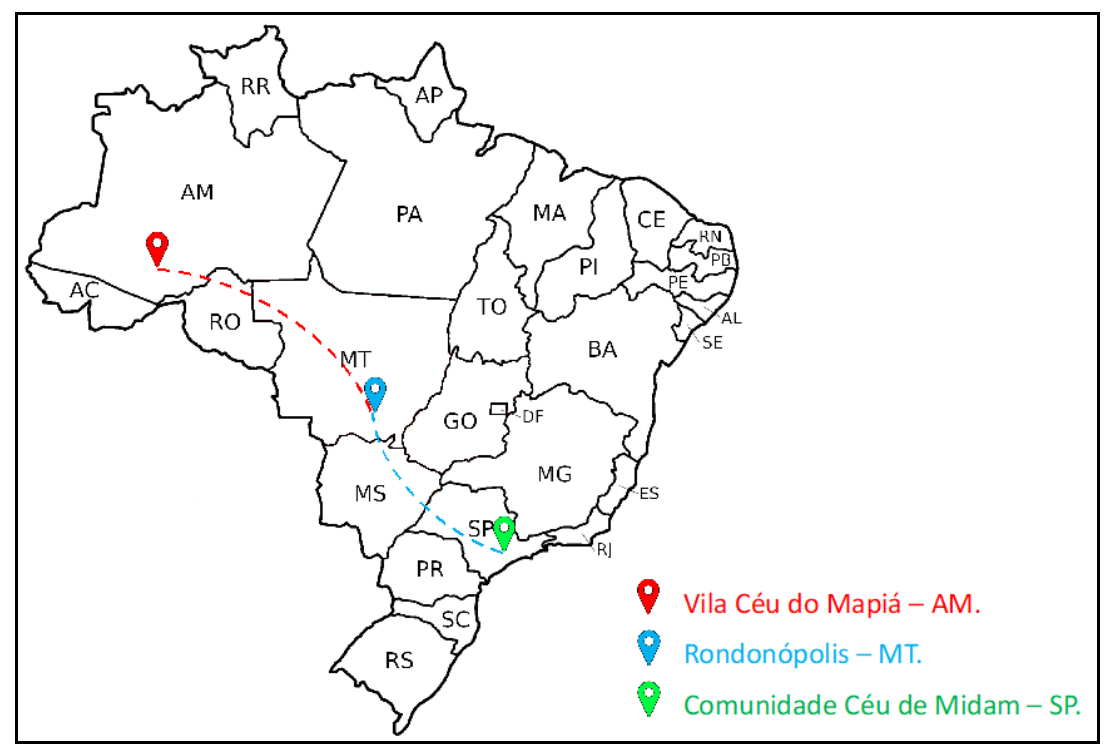

Figure 2 - The location of Vila Céu do Mapiá - AM, Rondonópolis - MT and Comunidade Céu de Midam, Piedade - SP. Source: AMF (2019).

Both plants are endemic to the Brazilian flora. Thus, P. viridis (queen) is endemic to northern Brazil (the states of Acre and Amazonas) and southeast Brazil (Minas Gerais and São Paulo). However, during its displacement within the Brazilian flora (from Amazonas to Mato Grosso and finally, to São Paulo), this plant was cultivated in Mato Grosso State, and since it is not native to this state/ecosystem, it may have had some environmental influence.

bICEFLU is the religious institution that promotes the doctrine of Santo Daime. It is responsible for all matters pertinent to the spiritual sphere, such as ritual norms, the use of Santo Daime, the study of singing and music, the training of managerial staff, and the planting, production and distribution of Santo Daime to affiliated groups. 
The same holds for B. caapi (jagube), which is endemic to the Brazilian flora in the north (Acre, Amazonas, Pará and Rondônia) and the midwest (Mato Grosso). The jagube seedlings brought from Rondonópolis, Mato Grosso, remained in their region of origin, even when they were taken from Vila Céu de Mapiá, Amazonas, to Rondonópolis, Mato Grosso. However, when this plant was brought to the southeast, specifically, the state of São Paulo, it was outside its region of origin, or rather, it was cultivated in the Comunidade Céu de Midam, a place where it is not naturally found, as it is not endemic to southeastern Brazil. Therefore, in the same way as $P$. viridis, it may have had some environmental influence.

The identities of the plants collected at the CLD were confirmed through the taxonomy of Banisteriopsis caapi (Spruce ex Griseb) and Psychotria viridis Ruiz \& Pav. (family Rubiaceae) carried out by Profa. Dra. Carla Poleselli Bruniera from the Universidade Federal de São Paulo. The taxonomy of Morton (family Malpighiaceae) was carried out by Profa. Dra. Maria Cândida Henrique Mamede from the Botanical Institute of São Paulo State (IBt-SP). Their deposits were made at the Herbarium of the Universidade Federal de São Paulo (HUFSP) under the Voucher numbers of HUFSP 423, 425, 426, 429, 430 and 431 (P. viridis) and HUFSP 424, 427, 428 and 433 (B. caapi).

In the present study, the CLD priest explained that the beverages are prepared during rituals called feitios in Portuguese, which take place when the stock for the rituals is low. These feitios usually occur during the new moon phase of the month, regardless of the day of the week. During the fieldwork, three feitios were conducted by the CLD community; however, the researchers were not authorized to participate in any of them, as the community explained that it is a sacred moment for the CLD and only its priests and leaders can participate.

Polari ${ }^{44}$ explains that the feitio is the great work of the doctrine because it presents the opportunity to produce the Daime (ayahuasca beverage) that is consumed in the rituals. The feitio follows strict ritual rules, with maximum respect, silence, devotion and physical effort. Polari44 also explains that during this ritual, the adepts/community members ingest the beverage, which is considered a sacrament, and sing hymns throughout the ritual. According to the leaders of the CLD, feitios usually last approximately two to three days, depending on the number of plants available, and involve the participation of several adepts, who gather in a special place called a barracão for the collection, cleaning and preparation of the plants needed to produce the beverage. This ritual process involves several stages, according to Polari ${ }^{45}$, including the location of the raw material in the forest (jagube and queen). Women are responsible for collecting and cleaning the queen leaves. At the CLD, the priests explained that women should wear a skirt for this task. The men harvest, clean and shave the vines, and after cleaning, the tapping activity (macerating the vines) begins. Pans are assembled with layers of macerated vines and interspersed with leaves, and water is then added to the furnace (kind of wood stove) ${ }^{45}$. The feitor is the person responsible for this ritual; he is usually initiated in this task by the Daimist masters of Amazon State. The recipes for each beverage have been passed orally from "feitor to feitor" since the time of Mestre Irineu, and they have been maintained up to now ${ }^{46}$. In the CLD, the production of the beverage is performed by several feitores who have accumulated the knowledge together with the Daimist brotherhood of Céu do Mapiá (Amazonia).

In the CLD, the beverage known as the "First Degree beverage" is prepared using approximately $40 \mathrm{~kg}$ of vines (B. caapi) and $18 \mathrm{~kg}$ of leaves ( $P$. viridis). The plants are arranged in alternating layers of vines and leaves in a pan of approximately 100 liters. After being arranged in the pan, the pan is filled with water and taken to the fire for cooking (decoction) for however long it takes for the pan's content to be reduced by $50 \%$, which can take hours. After this reduction, the beverage is placed in glass or plastic jars, usually with labels that contain the date of the preparation and the name "First Degree". Everything occurs under the supervision of the feitor and his helpers. To make the "Second Degree beverage", generally, a new pan is assembled with approximately $40 \mathrm{~kg}$ of vines (B. caapi) and $18 \mathrm{~kg}$ of leaves ( $P$. viridis), and the content of the "First Degree beverage" (50\% reduction ready) is added; the pan is then filled with water and cooked on the fire (decoction) for several hours. After the content of the new pan is reduced by $50 \%$, the "Second Degree beverage" is ready and is 
labeled in the same way as the previous recipe. Other possibilities for grading the beverage are possible, depending on the quantity and quality of the material (plants); theoretically, the beverage can go up to the "Ninth Degree beverage".

Regarding the beverage grades, from a pharmacological point of view, when the "degree" is higher, the beverage is more potent; that is, higher degree beverages are probably richer beverages from a chemical and pharmacological perspective. Nevertheless, among the various types of ayahuasca beverages, there is a so-called "honey beverage", which results from a reduction (thickening) that can be carried out with any type of ayahuasca beverage (First Degree, Second Degree, etc.) until it thickens and turns into "honey" (similar to the consistency of bee honey). This type of beverage was developed to facilitate transportation so that it would be more economical to transport larger quantities, including exporting to churches outside Brazil.

Studies have acknowledged that there is a variation in the plants used in the ayahuasca beverage; for example, the species $B$. caapi is composed of different "types" of vines, and Langdon ${ }^{47}$ documented at least 18 types of this species used by the Siona people from the Upper Amazonas Basin region. Additionally, Schultes and Hofmann ${ }^{48}$ observed that the natives of the Amazon recognize at least 30 different types of this species with different uses in their traditional medicine, and Peruvian ayahuasqueiros claim to distinguish up to 10 different types of species ${ }^{49}$. P. viridis is a genus of large shrubs and small trees (including approximately 1,400 species) found in tropical regions around the world ${ }^{5,49}$. Many other species are morphologically similar to $P$. viridis, and some are probably used to prepare ayahuasca, such as Psychotria cartagenensis, Psychotria leiocarpa and Diplopterys cabrerana, according to Brito ${ }^{5}$ and McKenna et al. ${ }^{49}$

Labate $^{6}$ reports that until a few years ago, most Daimist churches used the Daime (ayahuasca beverage) made in Céu do Mapiá (Amazon), which shared their products with the churches. Currently, the CLD produces its own Daime (ayahuasca beverage), and its production is increased or decreased according to the consumption demand of the CLD itself.

It was observed that the beverage is produced with the plants grown at the CLD; however, it is important to note that other plants (not identified) from different regions (Minas Gerais, Northeast, and Amazon) can also be utilized in producing the beverage; however, these plants were not collected and/or identified since they were not available during our fieldwork. These observations verify that there is not only one kind of ayahuasca beverage, but there are several beverages that vary based on the cooking time, concentration, and diversity of plants used. These variables directly affect the different "potencies" of the beverage from a chemical and pharmacological point of view.

It was also verified that it is quite common for church priests to offer the ayahuasca beverage as a gift. The CLD has stores of more than twenty types of ayahuasca beverages that have been saved over the years. According to the priests, each of them has unique characteristics that range in terms of the quality of the plants used to the preparation methods used.

According to the priests of the CLD, the amount of Daime (ayahuasca beverage) offered to adepts during the rituals follows the recommendations of the ICEFLU ${ }^{50}$. Labate ${ }^{6}$ reports that the official recommendations are to initially serve a dose of $120 \mathrm{ml}$ of "First Degree" Daime (ayahuasca beverage), $70 \mathrm{ml}$ of "Second Degree" Daime, or $40 \mathrm{ml}$ of "Third Degree" Daime. These are references for the maximum doses to be taken in the first "despacho" (dispatch). The next doses, consumed during the ritual on the same day, should be smaller. Regarding the repeated doses of the ayahuasca beverage during the rituals, Labate ${ }^{6}$ notes that these should successively decrease; for example, the second dose should be reduced by one-third and the third dose should be reduced by half. If there are more "dispatches" of the beverage, then they must always be optional, according to the official recommendations of the Centro Eclético da Fluente Luz Universal Raimundo Irineu Serra (CEFLURIS).

"According to CEFLURIS, "despacho" (dispatch) is a term used in the Santo Daime Doctrine for the distribution of the ayahuasca beverage. The person responsible for the "dispatch" is an adept with experience and familiarity within Daimist Doctrine. In most rituals, three doses of the ayahuasca beverage are dispatched at different times. ${ }^{6,50}$ 
When offering the ayahuasca beverage to adepts, according to the leaders of the CLD, there are special precautions that must be followed. When participating in the ritual, it is mandatory, especially for beginners, to carry out the anamnesis interview and to sign the Terms of Commitment for their future work. These recommendations are followed by the CLD, according to its priests (a godmother and godfather) ${ }^{50}$.

Scientific studies have demonstrated the structural chemical similarity between the neurotransmitter 5-HT and DMT, which justifies its psychodysleptic effect on the central nervous system (CNS). The chemical structures of the main alkaloids present in the ayahuasca beverage, specifically, the DMT extracted from the leaves and the main $\beta$-carbolines (HRM, $H R L$ and $T H H$ ) extracted from the vine, are all represented in Figure $3^{7,51}$.

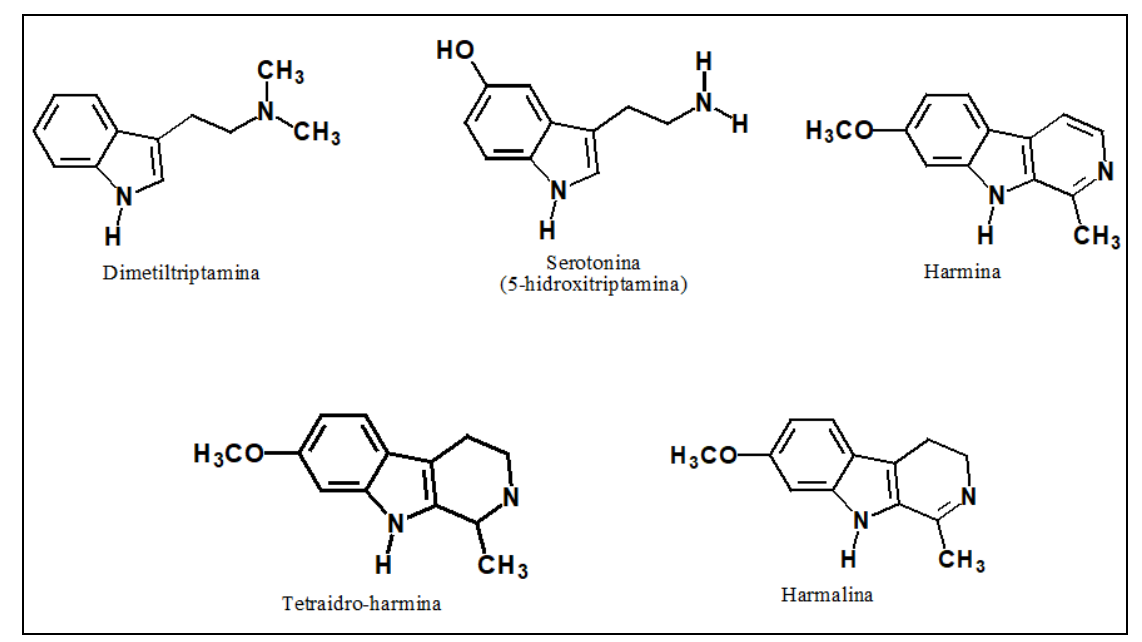

Figure 3 - The chemical structures of the main alkaloids present in ayahuasca and the similarity between the neurotransmitter 5-HT and DMT. Source: Pires et al. ${ }^{51}$

Ayahuasca works as an agonist of the serotonergic system, as the DMT present in the drink is similar to $5-\mathrm{HT}$. Studies have shown that DMT has a strong affinity for serotonergic receptors, especially subtypes $5-\mathrm{HT}_{1 \mathrm{~A}}, 5-\mathrm{HT}_{2 \mathrm{~A}}$, and $5-\mathrm{HT}_{2 \mathrm{c}}$. In relation to $\mathrm{B}$-carbolines, these substances act as indirect serotonergic agonists because by inhibiting the enzyme monoamine oxidase (MAO), especially MAO-A, they increase $5-\mathrm{HT}$ levels in the brain ${ }^{51,52}$. In corroborating these observations, subsequent studies have demonstrated a high affinity of these substances for serotonergic receptors, more specifically, they cause the stimulation of $5-\mathrm{HT}_{2 \mathrm{~A}}$ receptors and possibly the modulation of the action of $5-\mathrm{HT}_{2 \mathrm{C}}$ receptors ${ }^{51,53}$.

When ingested, DMT is not active because it is neutralized by the MAO enzyme present in the gastrointestinal tract and in the liver; however, $\beta$-carbolines (HRM, HRL and THH) present in the vine temporarily inhibit the action of the MAO enzyme and allow DMT to reach the CNS. Therefore, the pharmacological activity of ayahuasca depends on the synergistic interaction between the active alkaloids present in the two plants ${ }^{51,54,55}$. Ayahuasca can induce gastrointestinal disorders, such as nausea, vomiting and diarrhea. One explanation for these effects is that $5-\mathrm{HT}$ is a key signaling molecule in both the gut and the brain ${ }^{56}$. Approximately $95 \%$ of $5-\mathrm{HT}$ is located in the gastrointestinal tract, and the remaining $5 \%$ is located in the brain $^{57,58}$. Additional 5-HT receptors are present in the brain and intestine, although they have different functions in their respective locations. Peripheral $5-\mathrm{HT}$ is located in platelets, mast cells and enterochromaffin cells, where it modulates motility and digestive functions in the gastrointestinal system ${ }^{59,60}$. The $5-\mathrm{HT}_{2 \mathrm{~A}}$ brain receptor, for example, the main target of psychodysleptics, is peripherally involved in the contraction of the smooth muscles of the intestine and is centrally involved in cognitive processes and in higher-order moods ${ }^{58}$.

Serotonin $5-\mathrm{HT}_{2 \mathrm{~A}}$ receptors are widely distributed in the CNS, especially in the anterior medial brain region, and they play a key role in memory and cognition ${ }^{61,62} .5-\mathrm{HT}_{2 \mathrm{~A}} \mathrm{R}$ performs 
many functions in, for example, learning, memory, hallucinations, spatial cognition, mental disorders and substance abuse ${ }^{62,63}$.

A study conducted by Fonseca et al. ${ }^{64}$ evaluated and compared the neuropsychological profile of experienced ${ }^{d}$ adepts and beginners who adhere to the Santo Daime Doctrine and belong to the CLD, Comunidade Céu de Midam, Piedade, São Paulo. The results indicated that the more experienced group showed superior performance in tasks that involved working memory (verbal and visuospatial), which suggests an unprecedented finding regarding experienced users of ayahuasca in a ritual context.

The role of the $5-\mathrm{HT}_{2 \mathrm{~A}} \mathrm{R}$ receptor, according to Zhang and Stackman Jr ${ }^{62}$, is closely related to the functions that involve working memory and spatial cognition, which indicates that the prolonged use of ayahuasca may favor these cognitive functions. Preclinical studies suggest that HRM may have neuroprotective and cognitive enhancement effects; therefore, the prolonged use of ayahuasca, which is rich in HRM, may be associated with better neuropsychological functioning ${ }^{31}$.

Studies with an interest in the biological properties of ayahuasca have investigated laboratory methods for extracting active compounds from ayahuasca for use in antimicrobial medications ${ }^{65}$ and antiparasitic medicine ${ }^{66}$; for treating depression ${ }^{24}$, anxiety ${ }^{27}$, and Parkinson's ${ }^{67}$; for reducing dependency ${ }^{21}$; and to increase neuropsychological functioning ${ }^{31}$.

However, it is important to note that ayahuasca can have adverse effects. The DMT present in the ayahuasca beverage quickly increases both heart rate and blood pressure. $\beta$ carbolines (HRM, HRL and THH) contribute to the increase in the amount of 5-HT in the synaptic cleft, and their excessive accumulation can produce a series of adverse reactions, such as emetic effects, diarrhea, tremors, sweating, autonomic instability, hyperthermia, muscle spasms, changes in blood pressure, a loss of motor control, spatiotemporal disorientation, and possibly death caused by serotonin syndrome ${ }^{54,68}$.

One association that should be avoided is the use of ayahuasca with antidepressant medications in the class of selective serotonin reuptake inhibitors (SSRIs), since the double inhibition of the reuptake of 5-HT, by both SSRIs and B-carboline THH, causes increased 5-HT levels in the synaptic cleft and body organ s $^{51,55,69}$. Another strictly contraindicated association is that between ayahuasca and MAO-inhibiting antidepressants (MAOIs) ${ }^{53,69}$. The $B$-carbolines present in the ayahuasca beverage also maintain the potential for adverse interactions with CNS-stimulating substances, such as amphetamines, 3,4-methylenedioxymethamphetamine (MDMA) and methylphenidate ${ }^{53}$.

\section{CONCLUSION}

From the information collected through ethnographic research, it is concluded that Jonas Frederico was the founder of the Igreja Flor de Luz and the Comunidade Céu de Midam (CLD), Piedade, São Paulo and that the CLD was founded on November 15, 2002.

The identities of Psychotria viridis Ruiz \& Pav. (family Rubiaceae) and Banisteriopsis caapi (Spruce ex Griseb.) Morton (family Malpighiaceae) cultivated at the CLD were confirmed through botanical taxonomy. The CLD utilizes these plants to produce the ayahuasca beverage with various recipes; however, it is known that other plants are also occasionally utilized. This practice yields different types of beverages with variations in cooking time, concentration, and diversity and number of plants used in each recipe.

Future chemical and pharmacological studies should take into account the different recipes for the ayahuasca beverage in their investigations, as described in the present study, as each recipe may contain different amounts and proportions of the active alkaloids present. By considering the different recipes, the pharmacokinetic and pharmacodynamic effects of ayahuasca and its components will be better understood in academia.

\footnotetext{
${ }^{\mathrm{d}}$ Adepts are individuals with more than 20 years of experience using ayahuasca in rituals, and beginners are individuals with less than 3 years of ritual ayahuasca use.
} 


\section{ACKNOWLEDGMENTS}

Our thanks to the leaders of CLD, Piedade - SP and all the volunteers of this study.

\section{REFERENCES}

1. Luna LE. Indigenous and mestizo use of ayahuasca an overview. In: Santos RG, editor. The ethnopharmacology of ayahuasca [Internet]. Kerala: Transworld Research Network; 2011. p. 1-21 [cited 2021 Jan 28]. Available from: https://issuu.com/researchsignpost/docs/rafael

2. Assis GL, Rodrigues JA. De quem é a ayahuasca? Notas sobre a patrimonialização de uma "bebida sagrada" amazônica. Relig Soc. 2017;37(3):46-70. http://dx.doi.org/10.1590/010085872017v37n3cap02.

3. Coe MA, McKenna DJ. The therapeutic potential of ayahuasca. In: Camfield D, McIntyre E, Sarris J, editors. Evidence-based herbal and nutritional treatments for anxiety in psychiatric disorders. Cham: Springer; 2017. p. 123-37. http://dx.doi.org/10.1007/978-3-319-42307-4_7.

4. Hamill J, Hallak J, Dursun SM, Baker G. Ayahuasca: psychological and physiologic effects, pharmacology and potential uses in addiction and mental illness. Curr Neuropharmacol. 2019;17(2):108-28. http://dx.doi.org/10.2174/1570159X16666180125095902. PMid:29366418.

5. Brito GS. Farmacologia humana da hoasca (chá preparado de plantas alucinógenas usado em contexto ritual no Brasil). In: Labate BC, Araújo WS, editors. O uso ritual da ayahuasca. Campinas: Mercado de Letras; 2002. p. 623-51.

6. Labate BC. A Reinvenção do uso da ayahuasca nos centros urbanos. Campinas: Mercado de Letras, São Paulo: FAPESP; 2004. 470 p.

7. Santos BWL, Oliveira RC, Sonsin-Oliveira J, Fagg CW, Barbosa JBF, Caldas ED. Biodiversity of $\beta$ carboline profile of banisteriopsis caapi and ayahuasca, a plant and a brew with neuropharmacological potential. Plants. 2020;9(7):870. http://dx.doi.org/10.3390/plants9070870. PMid:32660098.

8. Goulart SL. A política das religiões ayahuasqueiras brasileiras: droga, religião e direitos. Relig Soc. 2019;39(2):200-21. http://dx.doi.org/10.1590/0100-85872019v39n2cap08.

9. Assis GL, Labate BC. Um panorama da literatura sobre a internacionalização das religiões ayahuasqueiras brasileiras. Ciênc Soc Unisinos. 2017;53(2):242-52. http://dx.doi.org/10.4013/csu.2017.53.2.08.

10. MacRae E. O ritual do Santo Daime como espetáculo e performance. In: Teixeira J, Gusmão R, editors. Performance, cultura \& espetacularidade. Brasília: Editora UNB; 2000. p. 75-84.

11. MacRae E. Guiado pela lua xamanismo e uso ritual da ayahuasca no culto do Santo Daime. São Paulo: Editora Brasiliense; 1992. 163 p.

12. Luna LE. Xamanismo amazônico, ayahuasca, antropomorfismo e mundo natural. In: Labate BC, Araújo WS, editors. O uso ritual da ayahuasca. Campinas: Mercado de Letras; 2002. p. 181-200.

13. Goulart SL, Labate BC, Carneiro H. Introdução. In: Labate BC, Goulart SL, editors. O uso ritual das plantas de poder. Campinas: Mercado de Letras; 2005. p. 29-56.

14. Lira WL. Xamanismo e enteogenia ameríndia: a ayahuasca e outras "plantas de poder" em contextos indigenistas e vegetalistas amazônicos. Aceno [Internet]. 2018 [cited 2021 Jan 28];5(10):59-78. Available from:

https://periodicoscientificos.ufmt.br/ojs/index.php/aceno/article/view/7131

15. Bastos FIPM, Vasconcellos MTLD, De Boni RB, Reis NBD, Coutinho CFDS. III levantamento nacional sobre o uso de drogas pela população brasileira [Internet]. Rio de Janeiro: FIOCRUZ/ICICT; 2017 [cited 2021 Jan 28]. Available from: https://www.arca.fiocruz.br/handle/icict/34614

16. McKenna, D. J. Clinical investigations of the therapeutic potential of ayahuasca: rationale and regulatory challenges. Pharmacol Ther. 2004;102(2):111-29. http://dx.doi.org/10.1016/j.pharmthera.2004.03.002.

17. Canal CE, Murnane KS. The serotonin 5-HT2C receptor and the non-addictive nature of classic hallucinogens. J Psychopharmacol. 2017;31(1):127-43.

http://dx.doi.org/10.1177/0269881116677104. PMid:27903793. 
18. Cruz JI, Nappo SA. Is ayahuasca an option for the treatment of crack cocaine dependence? J Psychoactive Drugs. 2018;50(3):247-55. http://dx.doi.org/10.1080/02791072.2018.1447174. PMid:29608428.

19. Mercante MS. Ayahuasca, dependência química e alcoolismo. Ponto Urbe. 2009;5. http://dx.doi.org/10.4000/pontourbe.1345.

20. Mercante MS. A ayahuasca e o tratamento da dependência. Mana. 2013;19(3):529-58. http://dx.doi.org/10.1590/S0104-93132013000300005.

21. Talin P, Sanabria E. Ayahuasca's entwined efficacy: an ethnographic study of ritual healing from 'addiction'. Int J Drug Policy. 2017;44:23-30. http://dx.doi.org/10.1016/j.drugpo.2017.02.017. PMid:28432902.

22. Winkelman M. Psychedelics as medicines for substance abuse rehabilitation: evaluating treatments with LSD, Peyote, Ibogaine and Ayahuasca. Curr Drug Abuse Rev. 2014;7(2):101-16. http://dx.doi.org/10.2174/1874473708666150107120011. PMid:25563446.

23. Osório FL, Sanches RF, Macedo LR, Santos RG, Maia-de-Oliveira JP, Wichert-Ana L, Araujo DB, Riba J, Crippa JA, Hallak JE. Antidepressant effects of a single dose of ayahuasca in patients with recurrent depression: a preliminary report. Braz J Psychiatry. 2015;37(1):13-20. http://dx.doi.org/10.1590/1516-4446-2014-1496. PMid:25806551.

24. Palhano-Fontes $F$, et al. Rapid antidepressant effects of the psychedelic ayahuasca in treatmentresistant depression: a randomized placebo-controlled trial. Psychol Med. 2019;49(4):655-63. http://dx.doi.org/10.1017/S0033291718001356. PMid:29903051.

25. Sanches RF, Osório FL, Santos RG, Macedo LRH, Maia-de-Oliveira JP, Wichert-Ana L, Araujo DB, Riba J, Crippa JAS, Hallak JEC. Antidepressant effects of a single dose of ayahuasca in patients with recurrent depression: a SPECT study. J Clin Psychopharmacol. 2016;36(1):77-81. http://dx.doi.org/10.1097/JCP.0000000000000436. PMid:26650973.

26. Barbosa PCR, Giglio JS, Dalgalarrondo P. Altered states of consciousness and short-term psychological after-effects induced by the first time ritual use of ayahuasca in an urban context in Brazil. J Psychoactive Drugs. 2005;37(2):193-201. http://dx.doi.org/10.1080/02791072.2005.10399801. PMid:16149333.

27. Santos RG, Landeira-Fernandez J, Strassman RJ, Motta V, Cruz APM. Effects of ayahuasca on psychometric measures of anxiety, panic-like and hopelessness in Santo Daime members. J Ethnopharmacol. 2007;112(3):507-13. http://dx.doi.org/10.1016/j.jep.2007.04.012. PMid:17532158.

28. Lima da Cruz RV, Moulin TC, Petiz LL, Leão RN. A single dose of 5-MeO-DMT stimulates cell proliferation, neuronal survivability, morphological and functional changes in adult mice ventral dentate gyrus. Front Mol Neurosci. 2019;12:312. http://dx.doi.org/10.3389/fnmol.2018.00312. PMid:31019450.

29. Morales-García JA, de la Fuente Revenga M, Alonso-Gil S, Rodríguez-Franco MI, Feilding A, PerezCastillo A, Riba J. The alkaloids of Banisteriopsis caapi, the plant source of the Amazonian hallucinogen Ayahuasca, stimulate adult neurogenesis in vitro. Sci Rep. 2017;7(1):5309. http://dx.doi.org/10.1038/s41598-017-05407-9. PMid:28706205.

30. Dakic V, Maciel RM, Drummond H, Nascimento JM, Trindade P, Rehen SK. Harmine stimulates proliferation of human neural progenitors. PeerJ. 2016;4:e2727. http://dx.doi.org/10.7717/peerj.2727. PMid:27957390.

31. Dos Santos RG, Hallak JE. Effects of the natural $\beta$-carboline alkaloid harmine, a main constituent of ayahuasca, in memory and in the hippocampus: a systematic literature review of preclinical studies. J Psychoactive Drugs. 2017;49(1):1-10. http://dx.doi.org/10.1080/02791072.2016.1260189. PMid:27918874.

32. Bernard HR. Research methods in cultural anthropology. Califórnia: Sage Publications; 1988. 520 p.

33. Foote-Whyte W. Treinando a observação participante. In: Guimarães AZ, editor. Desvendando máscaras sociais. 3. ed. Rio de Janeiro: Ed. Francisco Alves; 1990. p. 77-86.

34. Alexiades MN. Selected guidelines for ethnobotanical research: a field manual. New York: The New York Botanical Garden; 1996. 306 p.

35. Ona G, Kohek M, Massaguer T, Gomariz A, Jiménez DF, Dos Santos RG, Hallak JEC, Alcázar-Córcoles MA, Bouso JC. Ayahuasca and public health: health status, psychosocial well-being, lifestyle, and 
coping strategies in a large sample of ritual ayahuasca users. J Psychoactive Drugs. 2019;51(2):135-45. http://dx.doi.org/10.1080/02791072.2019.1567961.

36. Pargament Kl, Park CL. Merely a defense? The variety of religious means and ends. J Soc Issues. 1995;51(2):13-32. http://dx.doi.org/10.1111/j.1540-4560.1995.tb01321.x.

37. Machado JLC, Holanda AF. Religiosidade e bem-estar psicológico no contexto da clínica psicoterápica: um estudo fenomenológico. In: Freitas MH, Zaneti NB, Pereira SHN, editors. Psicologia, religião e espiritualidade. Curitiba: Juruá; 2016. p. 63-83.

38. Sanchez ZM, Nappo SA. A religiosidade, a espiritualidade e o consumo de drogas. Rev Psiq Clín. 2007;34(suppl 1):73-81. http://dx.doi.org/10.1590/S0101-60832007000700010.

39. Assis CL, Faria DF, Lins LFT. Bem-estar subjetivo e qualidade de vida em adeptos de Ayahuasca. Psicol Soc. 2014;26(1):224-34. http://dx.doi.org/10.1590/S0102-71822014000100024.

40. Freitas Melo C, Sampaio IS, Abreu Souza DL, Santos Pinto N. Correlação entre religiosidade, espiritualidade e qualidade de vida: uma revisão de literatura. Estud Pesqui Psicol. 2015;15(2):447-64. http://dx.doi.org/10.12957/epp.2015.17650.

41. Labate BC. Dimensões legais, éticas e políticas da expansão do consumo da ayahuasca. In: Labate BC, Goulart SL, editors. O uso ritual das plantas de poder. Campinas: Mercado de Letras; 2005. p. 397-458.

42. Brasil. Senado Federal. Lei $n^{\circ} 13.715$ de 24 de setembro de 2018 . Altera o Decreto-Lei $n^{\circ} 2.848$, de 7 de dezembro de 1940 (Código Penal), a Lei n 8.069, de 13 de julho de 1990 (Estatuto da Criança e do Adolescente), e a Lei n 10.406 , de 10 de janeiro de 2002 (Código Civil), para dispor sobre hipóteses de perda do poder familiar pelo autor de determinados crimes contra outrem igualmente titular do mesmo poder familiar ou contra filho, filha ou outro descendente. Diário Oficial da União [Internet]; Brasília; 25 set 2018; 3:1 [cited 2021 Jan 28]. Available from: https://legis.senado.leg.br/norma/27481236

43. Guareschi PA. Relações comunitárias relações de dominação. In: Campos HF, editor. Psicologia social comunitária: da solidariedade à autonomia. Petrópolis: Vozes; 1996. p. 81-99.

44. Polari A. O guia da floresta. 2. ed. Rio de janeiro: Record; 1992. 265 p.

45. Polari A. O livro das mirações: viagem ao Santo Daime. 2. ed. Rio de Janeiro: Record; 1995. 318 p.

46. Groisman A. Eu venho da floresta: um estudo sobre o contexto simbólico do uso do Santo Daime. Florianópolis: Editora da UFSC; 1999. 140 p.

47. Langdon EJ. Las clasificaciones del yagé Dentro del grupo Siona: Etnobotánica, etnoquímica e historia. Am Indig Aceno [Internet]. 1986 [cited 2021 Jan 28];46(1):101-16. Available from:

https://www.academia.edu/3346310/Las_clasificaciones_del_yag\%C3\%A9_dentro_del_grupo_Siona_etnobo t\%C3\%A1nica_etnoqu\%C3\%ADmica_e_historia

48. Schultes RE, Hofmann A. Plantas de los dioses: origenes del uso de los alucinógenos. 2. ed. México: Fondo de Cultura Económica; 2000. 208 p.

49. McKenna DJ, Towers GHN, Abbott F. Monoamine oxidase inhibitors in South American hallucinogenic plants: tryptamine and ß-carboline constituents of Ayahuasca.J Ethnopharmacol. 1984;10(2):195-223. http://dx.doi.org/10.1016/0378-8741(84)90003-5.

50. Igreja do Culto Eclético da Fluente Luz Universal - ICEFLU. Patrono Sebastião Mota de Melo [Internet]. Centro de Documentação e Memória; 2020 [cited 2021 Jan 28]. Available from: http://www.santodaime.org/site/

51. Pires APS, Oliveira CDR, Yonamine M. Ayahuasca: uma revisão dos aspectos farmacológicos e toxicológicos. Rev Cienc Farm Basica Apl [Internet]. 2010 [cited 2021 Jan 28];31(1):15-23. Available from: https://rcfba.fcfar.unesp.br/index.php/ojs/article/view/406/404

52. Santos RG, Bouso JC, Hallak JEC. Ayahuasca, dimethyltryptamine, and psychosis: a systematic review of human studies. Ther Adv Psychopharmacol. 2017;7(4):141-57. http://dx.doi.org/10.1177/2045125316689030. PMid:28540034.

53. Callaway JC, Grob CS. Ayahuasca preparations and serotonin reuptake inhibitors: a potential combination for severe adverse interactions. J Psychoactive Drugs. 1998;30(4):367-9. http://dx.doi.org/10.1080/02791072.1998.10399712. PMid:9924842.

54. Callaway JC, McKenna DJ, Grob CS, Brito GS, Raymon LP, Poland RE, Andrade EN, Andrade EO, Mash DC. Pharmacokinetics of Hoasca alkaloids in healthy humans. J Ethnopharmacol. 1999;65(3):24356. http://dx.doi.org/10.1016/S0378-8741(98)00168-8. PMid:10404423. 
55. McKenna DJ, Callaway JC, Grob CS. The scientific investigation of Ayahuasca: a review of past and current research. Heffter Rev Psychedelic Res [Internet]. 1998[cited 2021 Jan 28];1. Available from: https://www.erowid.org/chemicals/ayahuasca/ayahuasca_journal3.shtml

56. Fonseca AM. Introdução à psicofarmacologia e noções de tratamento farmacológico [livro eletrônico]. Guarujá: Científica Digital; 2021. 138 p. http://dx.doi.org/10.37885/978-65-87196-77-0.

57. Kim DY, Camilleri M. Serotonin: a mediator of the brain-gut connection. Am J Gastroenterol. 2000;95(10):2698-709. http://dx.doi.org/10.1111/j.1572-0241.2000.03177.x.

58. Kuypers KPC. Psychedelic medicine: the biology underlying the persisting psychedelic effects. Med Hypotheses. 2019;125:21-4. http://dx.doi.org/10.1016/j.mehy.2019.02.029.

59. Fotiou E, Gearin AK. Purging and the body in the therapeutic use of ayahuasca. Soc Sci Med. 2019;239:112532. http://dx.doi.org/10.1016/j.socscimed.2019.112532. PMid:31494522.

60. Sadock B, Sadock VA, Ruiz P. Compêndio de Psiquiatria: ciência do comportamento e psiquiatria clínica. 11. ed. Porto Alegre: Artmed; 2017. 1490 p.

61. Capela JP, Carvalho FD. Serotonina. In: Rego AC, Duarte CB, Oliveira C, editors. Neurociências. Lisboa: Lidel; 2017. p. 167-91.

62. Zhang G, Stackman RW Jr. The role of serotonin 5-HT2A receptors in memory and cognition. Front Pharmacol. 2015;6:225. http://dx.doi.org/10.3389/fphar.2015.00225. PMid:26500553.

63. Fongang B, Cunningham KA, Rowicka M, Kudlicki A. Coevolution of residues provides evidence of a functional heterodimer of 5-HT2AR and 5-HT2CR involving both intracellular and extracellular domains. Neuroscience. 2019;412:48-59. http://dx.doi.org/10.1016/j.neuroscience.2019.05.013. PMid:31158438.

64. Fonseca AM, Marteleto MRF, Rodrigues E. Perfil neuropsicológico de daimistas do Centro Luz Divina, SP, Brasil. Arq Bras Psicol. 2021. In press.

65. Pérez Marvit MJ. Optimización del método de extracción de $\beta$-carbolinas a partir de banisteriopsis caapi (ayahuasca) y caracterización del extracto para su posterior aplicación en modelos celulares con fines terapêuticos [trabajo fin carrera]. Quito: SEK International University; 2020. Available from: http://repositorio.uisek.edu.ec/handle/123456789/3747

66. Meneguetti DUO, Meneguetti NFSP. Benefícios a Saúde Humana ocasionado pela ingestão da Ayahuasca: contexto social e sua ação neuropsicológica, fisioimunológica, microbiológica e parasitária. Cad Bras Health Ment [Internet]. 2014 [cited 2021 Jan 28];6(13):104-21. Available from: http://stat.entrever.incubadora.ufsc.br/index.php/cbsm/article/view/2576/3634

67. Samoylenko V, Rahman MM, Tekwani BL, Tripathi LM, Wang YH, Khan SI, Khan IA, Miller LS, Joshi VC, Muhammad I. Banisteriopsis caapi, a unique combination of MAO inhibitory and antioxidative constituents for the activities relevant to neurodegenerative disorders and Parkinson's disease.J Ethnopharmacol. 2010;127(2):357-67. http://dx.doi.org/10.1016/j.jep.2009.10.030. PMid:19879939.

68. Gable RS. Risk assessment of ritual use of oral dimethyltryptamine (DMT) and harmala alkaloids. Addiction. 2007;102(1):24-34. http://dx.doi.org/10.1111/j.1360-0443.2006.01652.x. PMid:17207120.

69. Frecska $E$. The risks and potential benefits of Ayahuasca use from a psychopharmacological perspective. In: Labate BC, Jungaberle $\mathrm{H}$, editors. The internationalization of ayahuasca. Münster: LIT Verlag; 2011. p. 151-65.

\section{Author contributions}

AMF: conceptualization, methodology, research, statistical analysis, collection of botanical material, data collection, writing - preparation of the original project and the original draft; ER: conceptualization, methodology, research, supervision of the original project - review and supervision. 